\title{
International development assistance and food security
}

\author{
Trinity Economic Paper Series \\ Policy Paper No. 98/2 \\ JEL Classification: F35, Q18
}

\author{
Alan Matthews \\ Department of Economics \\ Trinity College \\ Dublin 2 \\ email: Alan.Matthews@tcd.ie
}

\begin{abstract}
Not only has development assistance overall been falling in volume terms, but the share of this ODA going to improving agriculture and nutrition in developing countries has also fallen. This paper investigates the reasons for the declining commitment of donors to these areas and whether this can be reversed. Favourable policy changes to encourage agricultural development in many developing countries, as well as the steps taken to open agricultural markets in the Uruguay Round, should help to improve the performance of agricultural aid projects and encourage greater donor commitment. Emphasis on a more poverty-focused agricultural development strategy would also help to build support among development NGOs in donor countries. The outlook for reversing the decline in food aid is less promising, although a series of food emergencies which greatly increased the numbers of refugees and displaced persons could alter this prognosis.
\end{abstract}

\section{Acknowledgements}

Helpful research assistance by Joanna O'Riordan is gratefully acknowledged. Views expressed are those of the author and do not necessarily reflect the views of the Department of Economics, Trinity College Dublin. 


\section{Introduction}

Food security exists when all people, at all times, have physical and economic access to sufficient, safe and nutritious food to meet their dietary needs and food preferences for an active and healthy life. In recent decades there has been a significant improvement in food security. Current food availabilities for the world as a whole were estimated at 2720 calories per person per day in 1990-92, up from 2300 calories in 1961-65 or an increase of 18 per cent (FAO, 1996a). Coupled with some small improvement in the way these global food supplies are distributed, the proportion of undernourished people in developing countries has fallen substantially from 35 per cent in 196971 to 21 per cent in 1990-92. This decline has taken place in all regions with the exception of Sub-Saharan Africa. Famines, which were once an almost inevitable occurrence in low-income societies, have been virtually confined in recent decades to conflict situations.

But progress has been uneven, leaving an unacceptably large number of undernourished or food-insecure individuals. FAO estimates that currently more than 800 million people suffer from malnutrition, with millions more at risk from sudden and unforeseen adverse shocks to food production, prices or supplies (op.cit.). The role of international assistance in promoting food security has been debated at two major international conferences in the past three decades, the World Food Conference in 1974 and the World Food Summit in 1996. Yet despite the evident need for co-ordinated international action to tackle the causes of hunger, in recent years there has been a steady falling-off in the international commitment to this goal. International aid to agriculture dropped dramatically during the 1990s. Food aid flows to developing countries peaked in 1993 and have fallen significantly since then. The 1996 World Food Summit attempted to

redress these trends and to refocus world attention on the problem of hunger, but 
the Declaration and Plan of Action adopted at the Summit contained little that was new in firm commitments. 1

Given the close relationship between poverty and food insecurity, a wide range of international actions indirectly impinge on food security. The overall level and terms of financial flows, the generosity of debt rescheduling and relief, market-opening trade policy measures and international economic co-ordination all vitally affect the economic growth prospects of the most food-insecure countries. To comprehensively cover all of the international actions which impact on food security is beyond the scope of this paper. Instead, it examines two areas where external support can prove useful to countries implementing food security strategies:

- by providing funds for investment in increasing food production, including agricultural research

- by providing food aid to meet emergencies and to raise the nutritional standards of particularly vulnerable households

The paper investigates the reasons for the declining commitment of donors to these areas and whether this can be reversed.

\section{Finance for agriculture and rural development}

The bulk of the development finance to agriculture is provided by countries belonging to the Development Assistance Committee (DAC) of the OECD and by the international financing institutions (IFIs) such as the World Bank and the Regional Banks. Official development finance includes both official development assistance (ODA) as well as flows on more commercial terms. Analysis of aid flows to agriculture and rural development ideally should

\footnotetext{
1 A balanced review of what the Summit achieved and failed to achieve is provided in
} 
be based on the net flow of resources to these sectors. However, there is no sectoral breakdown of the data on resource flow disbursements, nor is it feasible to net the gross flows to any individual sector such as agriculture. Under the circumstances, the best that can be done is to examine the trends in the commitments of external financial assistance to agriculture (Bhattacharjee, 1977). Data on commitments tend to exaggerate the actual flow of resources, in part because repayments of loans are not netted out, and in part because of the time lag between the commitment of assistance and its disbursement. We should also note that data on external assistance to agriculture are classified according to two definitions. The narrow definition includes activities directly contributing to the development of agricultural production such as crop and livestock development, fisheries, forestry, irrigation and land development, supply of fertilisers and other inputs, agricultural services and storage. The broad definition includes, in addition, agro-industries, rural infrastructure, construction of plants for fertilisers and other inputs and projects for rural, regional and river basin development.

After the food crisis in the early 1970s annual commitments in current terms on the broad definition rose to around US\$12 billion. This was maintained through the first half of the 1980s and increased to US\$15 billion towards the end of the decade. Thereafter commitments fell back to US\$12 billion in 1992 and have continued to decline since, falling to around US\$10 billion per year by 1995 . The fall during the 1990s appears even more marked if adjusted for inflation. In real terms, deflating by the UN unit value index for exports of manufactured goods, annual flows averaged just over $\$ 17$ billion (at 1990 prices) in the early 1980s and were only just below this figure in the years at the end of the 1980s. In the early 1990s they fell to $\$ 13$ billion and to just 
$\$ 10$ billion annually by the mid-1990s (Table 1). The fall in the assistance to production agriculture is even more stark as the sectoral statistics increasingly include support for environmental protection and natural resource management which, essential though they are, have less direct and immediate impact on food production. In regional terms, while Asia and Africa are the largest recipients in absolute terms, it is disturbing to note a greater retrenchment in agricultural aid commitments in Africa as compared to Asia during the 1990s given the very limited domestic savings capacity in Africa at the present time (FAO, 1997a).

The multilateral agencies have always been the most important source of development finance to agriculture and their share has varied between 55 and 65 per cent of the total. Lending to agriculture by the World Bank alone in most years exceeds bilateral aid to agriculture from the DAC countries. World Bank resources are not provided on concessional terms (except to the group of lowincome countries eligible for IDA financing), so it may be concluded from these figures that most external finance for agriculture is loan finance which must be repaid. Both multilateral and bilateral donors reduced their assistance to agriculture equally severely in the 1990s, although the share of the multilateral agencies recovered slightly from its relatively low point at the end of the 1980s. Total bilateral commitments from DAC countries have fluctuated around US $\$ 4$ billion annually during the past five years. Just over half of total bilateral commitments in 1995 came from Japan, which increased its share from one-third of the total in 1991. Germany was the second highest donor in 1995, followed by the Netherlands, the United States and France. The US share of bilateral agricultural aid has steadily decreased from more than $30 \%$ in the early 1980 s to less than $10 \%$ in 1995 (Table 2).

The proportion of a donor's total aid budget allocated to the agricultural sector is one measure of its commitment to this sector. The aggregate figures 
mask very large variations among individual donors in the changing shares of agricultural aid. The big drop in the proportion of total bilateral aid going to agriculture occurred in 1990. In the second half of the 1980s, assistance to agriculture averaged around 12 per cent of bilateral ODA; throughout the 1990s the figure has remained around 7.5 per cent. The biggest change in commitment to agriculture occurred in the US and among the 'Other' category of donors although the proportion of EU bilateral aid to agriculture and, to a smaller extent, Japanese aid also fell (Table 3).

Trends in bilateral aid are mirrored in the lending behaviour of the multilateral development banks. The most important lender, the World Bank, had a strictly agricultural portfolio with a commitment value of about US\$25 million in 1996 (17 per cent of the total Bank portfolio). Adding in the nonagricultural rural portfolio of projects classified in other sectors but with rural components, the total rural portfolio had a commitment value of US\$35 billion (24 per cent of the Bank total) (World Bank, 1996). However, World Bank new lending to agriculture, as a share of total lending, has fallen from 30 per cent in the mid-1980s to 12 percent in 1996 (Table 4). A recent analysis of EU aid (i.e. that portion of European Union aid which is managed by the European Commission) also demonstrated the sharp falling off in the commitment to agriculture by the EU, and particularly for more broadly-based rural development projects (Table 5).

\section{Investment needs and development assistance flows}

The relative scale of external assistance to agriculture can be illustrated using FAO data. FAO has estimated that net investments in on-farm improvements in developing countries may have been US\$26 billion per year in the recent past (US\$77 billion gross) and in the post-production sector US\$15 
billion per year (US\$34 billion gross). In addition to these largely private investments, public expenditure on research and extension in LDCs may be estimated at about US\$10 billion per year and on rural infrastructure at, very tentatively, US\$20 billion annually. Even with external assistance at the low levels in the mid-1990s of around US\$10 billion annually, it is clear that it has funded a significant share of public investment in the rural sectors of developing countries. For many of the poorer developing countries, external assistance is almost the only source of public investment in agriculture and to a large extent also of recurrent costs (FAO, 1996b).

As to future investment, FAO estimates that to increase food production in developing countries in line with effective demand until 2010, gross investment of some US\$86 billion will be required annually in primary agricultural production (including irrigation), US\$43 billion for related postproduction facilities and US\$37 billion for public support services and infrastructure. Nearly three-quarters of this future investment will consist of private commitments by farmers for land improvements, new equipment, expansion of livestock herds and plantations, and for private investments in the post-production chain. The remaining one-quarter, representing about US\$41 billion per year, will consist of complementary public investments to create and maintain the conditions for profitable private sector investment. If external multilateral and bilateral financial support for these public investments were to provide the same share as in the past, i.e. around one-third overall, external commitments would need to rise by some US $\$ 5$ billion per year, from US\$10 to US $\$ 15$ billion annually, i.e. to the level provided in the late 1980 s.

International net private capital flows into developing countries are now much more important than official development finance, having risen from US\$49 billion in 1990 to US\$234 billion in 1996, compared to total official 
development finance of about US\$66 billion net in the latter year (OECD 1998). However, little of this private investment went into primary agricultural production. Private finance has a role in funding programmes for plantation crops, large irrigation projects and other activities to do with input supply, processing and marketing which it can usually run more efficiently and more flexibly than government-run institutions. The World Bank has even supported the use of private sector institutions to carry out research and deliver information in ways that are more responsive to farmers' demands (World Bank, 1996). However, the record is that private investment is highly selective, going mainly to China and a handful of other growth centres in Asia and Latin America, and often requires complementary public sector investments to create the right opportunities. It would be naive to assume that agriculture's financing needs can be met from private sources alone, particularly in low-income food-deficit countries (LIFDCs). 2

\section{Reasons for agricultural aid fatigue}

Will donors be willing to meet the challenge of finding additional resources for agricultural development? To answer this question, it is necessary to understand why aid to agriculture has been falling in recent years. Previous work on trends in aid to agriculture undertaken at the International Food Policy Research Institute (IFPRI) distinguished two major categories of causes: economic and political economy. Economic reasons centre around the hypothesis that agricultural development assistance did not pay off and, therefore, donors turned elsewhere. Political economy reasons revolve around two hypotheses: that the power of political interest groups led to reduced

2 LIFDSs include all food-deficit countries with per caput incomes below the level 
emphasis on agriculture, and that certain bureaucratic distortions in aid agencies undermined a commitment to agriculture (von Braun et al., 1994). The continuing relevance of these arguments are briefly reviewed in this section.

The poor performance of many agricultural projects has not helped the case for additional resources. At the World Bank, a dismal 58 per cent of completed agricultural projects were judged satisfactory or better in the period 1981-89, ten percentage points worse than the Bank average (World Bank, 1996). There are various reasons why aided agricultural projects performed so poorly. In some cases, the original projects may have been poorly designed from a purely technical perspective. Second, even well-designed projects which would yield acceptable rates of return in a favourable macro-policy context can perform poorly if the general macroeconomic environment turns hostile. For example, commodity prices play an important role in the outcome of a project, and declining prices result in decreased returns. Third, in many countries unfavourable price trends may have been exacerbated by domestic policies seeking to promote non-agricultural sources of growth. The growing awareness of the key role of the macroeconomic environment in determining success or failure of agricultural projects led many donors to turn away from direct project lending towards support for structural adjustment and policy-based lending. Opportunities to invest in agricultural projects were ignored on the view that, until appropriate sectoral policies were adopted, specific project investments would fail (Von Braun et al, 1994).

While the poor return on agricultural projects helped to 'push' funding away from agriculture, the increased pressures for programme lending to support economic reforms and debt relief, as well as the desire to divert finance to the high-profile environmental protection and social sectors helped to 'pull' funding

used by the World Bank to determine eligibility for IDA assistance (i.e. US\$1305 in 1992). 
away from the sector. The rise in the share of social spending and the growth of programme lending in the late 1980s emerges clearly in Table 6. Social and environmental spending are undoubtedly important, but should be seen as complementary to aid to production agriculture rather than a substitute for it. For example, there is an important link between environmental protection and increases in agricultural production. Farmers who increase yields per unit of land have less reason to push into marginal, environmentally sensitive lands to meet food needs. And local resourcing for initiatives in the social sector, such as schools, health services etc. cannot be sustained without an improvement in the productive base of the economy.

From a political economy perspective, the allocation of development assistance is a product of competition among pressure groups in both donor and recipient states. Von Braun et al. (1994) argue there were several political market forces at work in the 1980s which acted to reduce the supply of development assistance to agriculture.

As the over-production of farm commodities in developed countries increased and prices fell, domestic farm lobbies increasingly opposed assistance which was perceived as increasing the supply capacity of potential markets. This was especially the case in the United States where the combination of increased production and an appreciating exchange rate put severe pressure on farm incomes in the 1980s. As the same time as farmer support for aid to agriculture was waning, other groups tried to influence the composition of aid in their favour. Financial institutions and banks were concerned at the ability of developing countries to service and repay loans and lobbied for adjustment lending to support macro and micro policy reforms. Nor did policy-makers in developing countries push for a higher priority for agriculture. Agriculture was often viewed as a declining sector, and therefore not important for development. 
Falling real food prices over two decades perhaps led to complacency. Urban interests still dominate in political systems where the rural poor have little voice.

In situations like this, the IFIs might have taken a more independent line in pushing the results of research findings which emphasise the critical role of developing agriculture for overall economic growth and the reduction in poverty, especially in low-income developing countries. However, von Braun et al. note two bureaucratic changes which undermined the willingness and ability of the IFIs to take a leadership role. First, in a number of donor agencies, including the World Bank, there was a shift away from functional units to regional departments. This meant there was no longer a single budget for agricultural projects for which different countries could compete; instead, agricultural projects in individual countries had to compete with other sector projects in those same countries. With agricultural projects performing poorly relative to other sectors, a declining agricultural share is not surprising. Second, the numbers of technically competent staff in agriculture was reduced, making it even more difficult to design successful projects to claw back some of the share which was lost.

\section{The contribution of food aid to food security}

Assisting food production is the first way in which international assistance can contribute to food security. Helping to overcome chronic malnutrition arising from lack of access to food is a second way. Traditionally, this has been a major rationale for food aid, and the commitment to raise cereal food aid to a minimum 10 million tonnes a year was one of the main achievements of the 1974 World Food Conference. Actual deliveries (including non-cereals food aid of between 1 and 2 million tonnes) peaked at almost 17 million tonnes in 1993, subsequently falling to 7.5 million tonnes in 1996 with forecasts for a similar 
volume in 1997. In the mid 1980s, gross cereal imports by developing countries amounted to around $100 \mathrm{~m}$ tonnes, of which around 12 million tonnes were supplied by food aid deliveries. By 1996, gross cereal imports had risen to around $150 \mathrm{~m}$ tonnes, but only 7.5 million were supplied by food aid. The significance of food aid is even more important for the LIFDCs, although a decline in its relative contribution to gross cereal imports has also occurred for these countries (Table 7).

Food aid as a proportion of overall ODA has gradually fallen from a high point of over 10 per cent in the mid-1980s to less than 5 per cent at the present. The US has traditionally been the largest single donor although its share of total food aid has been slipping. In 1996, 44 per cent of global deliveries were financed by the USA, 35 per cent by the European Union and its Commission, 6 per cent by Japan and 15 per cent by other donors. Food aid has generally accounted for around 15 per cent of total US ODA and this proportion has not altered much over time. The other important donor is the EU through its 'Community action', i.e. food aid disbursed through the EU budget. Food aid has traditionally represented a large proportion of EU aid, amounting to 26 per cent of the total in 1986. This proportion declined to 9-11 per cent of all EU aid between 1993-95 (Cox and Koning, 1997).

Associated with the decline in the overall volume of food aid there has been a shift in its use and distribution. Three categories of food aid can be distinguished: programme, relief and project aid. Programme aid is not targeted on specific groups. Rather it is provided on a bilateral basis to support recipient governments' budgets or reduce balance of payments deficits. Relief food aid is aimed at people suffering from natural or manmade disasters, such as drought or civil strife. Project food aid is provided to selected groups to support specific development objectives. The nutritional impact of the three categories of food 
aid varies. Relief and project aid most directly contributes to food security by providing additional food assistance. The major benefit of programme food aid is that it may substitute for commercial imports and thus release foreign exchange for general development purposes. Another significant difference between the categories is that a high proportion of programme aid is provided on concessional loan terms, whereas virtually all relief and project aid is provided in grant form.

About 50 per cent of global food aid deliveries in 1993-94 was provided as programme aid, 30 per cent as relief assistance, and 20 per cent as support for development projects. Since 1990/91, the use of food aid for emergencies has grown. In the 1980s, the annual amount of food aid for emergencies averaged 2.4 million tonnes, whereas over the last three years (1992-95) it averaged 4 million tonnes. This increase has been at the expense of both project and programme food aid.

During the 1960s, India was the main recipient of global food aid. Asia as a whole received nearly two thirds of all food aid in the form of cereals until the mid 1970s and remained the largest recipient region until 1980. At that point Sub-Saharan Africa became the main recipient region and its share of total food aid has remained fairly steady at around one-third of the total over the past decade. The main change in the geographical distribution of food aid in recent years has been the major reallocation of food aid to Europe and ex-USSR countries. At their peak these countries absorbed over one-third of total food aid, most of which was earmarked for balance of payments support. Their increased share was not at the expense of Sub-Saharan Africa but of Asia and, in particular, North Africa and the Middle East. Similarly, the main gainers from the reduced flows to Europe and the CIS region in 1995-96 have been the Asian countries. 
Because food aid is doubly tied, it is often seen as a less desirable form of aid. Falling food aid flows, from this perspective, may simply reflect a desirable adjustment in donors' portfolios. It is thus worth asking whether falling food aid is a threat to food security and whether additional food aid flows could make a positive contribution to reducing hunger.

Projections of food aid needs are made regularly by agencies such as the US Department of Agriculture and the World Food Programme. Studies of this kind forecast that food aid needs will nearly double by the middle of the next decade, even with optimistic assumptions about recipient countries' ability to produce their own food or to have the financial capacity to import food commercially. For example, a 1995 USDA study projected total food aid needs to maintain consumption and meet emergency needs for refugees at 15 million tonnes in 1996, rising to 27 million tonnes by 2005. More food aid would be required if recipient countries' financial capacity to import food commercially lagged or if the consumption target was to meet minimum nutritional standards (Shapouri, 1995). The increasing incidence of humanitarian crises and political turmoil in recent years is one factor behind the growing demand for food aid. Nonetheless, in the USDA study only 20 per cent of the needs are classified as emergency needs resulting from production variability and political conflict. About 80 per cent of the food aid needs are classified as chronic (prolonged). Given the forecasts for the continued growth in the absolute numbers of people malnourished by 2020, the role for food aid targeted on food insecurity is set to increase.

The debate continues, of course, as to whether these needs would not be better met by increased financial aid rather than food aid. The main defence of food aid is that it is not a substitute for financial aid but additional to it. The rationale for this argument is traced back to the origins of food aid in surplus 
disposal which effectively lowered the real or opportunity cost to donors of providing food aid. This is buttressed by the further argument that food aid is supported by a coalition of political forces which are attracted to food aid because of its specific characteristics (in providing an outlet for surplus agricultural commodities, or because it facilitates market development) and who would be unlikely to give support for financial aid of equivalent value. Additionality may also arise where food aid is the responsibility of ministries of agriculture and allocated separately from the mechanisms for deciding on financial aid.

A second defence of food aid as a preferred instrument to financial aid is that it is more likely to succeed in reaching the very poor and food-insecure. Food aid is seen as having a comparative advantage in reaching large numbers of the world's most vulnerable people. Particularly project food aid, used as a wage resource that transfers income to poor households through labour-intensive public works programmes, or as an incentive to children and mothers to attend school or health clinics, is of direct benefit to very food-insecure people in food deficit countries.

\section{Explanations for the decline in food aid}

Given these arguments in favour of food aid, the puzzle is to understand why food aid commitments have fallen sharply in recent years. Precisely because of its additional nature, the factors influencing the supply of food aid are not necessarily the same as those which explain the decline in external assistance to agriculture. Explanations can draw on two lines of enquiry into the factors which have influenced the supply of food aid. One is a statistical approach which tries to identify the major determinants of donors' propensity to grant food aid; the other is a political economy approach which focuses on the 
reasons why a country might prefer to provide food aid rather than financial aid or no aid at all.

Statistical analysis highlights the influence of the level of public stocks of agricultural commodities, the price of food aid commodities as well as evidence of need (Saran and Konandreas, 1991). Many donors accumulate public stocks as a result of domestic farm price support policies. These stocks are costly to store and in some cases may physically deteriorate in storage. There is often only a small likelihood that the stocks can be resold on the market at anything close to their purchase price. Giving these stocks away saves the resource costs of storage and avoids their price-depressing effect on world markets. The price of food aid commodities has also been shown to be an important factor affecting the level of food aid shipments. In the short-run food aid flows vary inversely with commodity prices. In many countries food aid budgets are fixed in nominal rather than volume terms; as commodity prices rise, less food can be bought. The analysis also reveals that donors in general have responded positively to the increased needs in recipient countries arising from short-term production shortfalls, although the response is only a partial one and covers only a small fraction of the cereal production shortfalls experienced.

More generally, the multiplicity of objectives of donors' food aid programmes is well documented. Programmes combine diplomatic, commercial, humanitarian, surplus disposal and development objectives to varying degrees. Support for food aid will respond to the shifting balance between different domestic constituencies whose interests it affects. In the US, for example, the general farm organisations have been strong supporters of food aid programmes in the past. As the US has adopted more market-oriented farm policies and the likelihood of surpluses reduces, the farm interest group constituency for food aid has diminished. Increasingly, export enhancement programmes outside of food 
aid are preferred as a more effective way of disposing of surpluses (Ruttan, 1993)

The link between food aid and surplus disposal has also weakened for other reasons. Food aid is increasingly competitive with financial aid. In the US, for example, the Gramm-Hollings-Rudman Amendment shifted the attributable cost of PL480 to the foreign assistance budget (Clay and Stokke, 1991). In the EU food aid is very deliberately not seen as linked to surplus disposal. In 1988, for example, despite the very limited availabilities and high prices in EU and world markets, the EU maintained the quantity of dairy products in its food aid programme at the level of previous years. For the individual EU member states, bilateral food aid programmes (known as 'national actions' as distinct from 'Community actions') are funded from national aid budgets and are not directly linked to the surpluses generated by the EU's Common Agriculutral Policy in any case (Saran and Konandreas, 1991). The gradual diversification of sources of food aid since the late 1960s to include most industrialised countries has also made the link between food aid and surplus disposal more tenuous.

Paradoxically, de-linking food aid from surplus disposal has not increased its popularity with the other important constituency of voluntary development organisations. Non-emergency food aid is frequently criticised by the development NGOs, in spite of their growing involvement in the delivery of food aid for nutritional objectives. Many of the criticisms of food aid are based on arguments well rehearsed in the academic literature, such as the alleged disincentive effects of food aid in recipient countries, the possibility that it can undermine local food markets and encourage the growth of inappropriate food tastes. As a consequence of such criticisms, official food aid programmes are now more firmly embedded in a food security framework (see, for example, European Council, 1996). 
Saran and Konandreas (1991) argue that the opportunity cost of food aid is an important factor behind food aid decisions. Food aid donations tend to raise the commercial price of food aid commodities above what they would be in the absence of food aid and the revenue gain on commercial sales (for exporters) helps to offset the revenue loss from providing some food as aid. The size of this world price effect depends on the relative elasticities of demand in the commercial and food aid markets, as well as on the degree of leakage of food aid commodities from the food aid to the commercial market. For exporting countries over the period 1971 and 1988 the opportunity cost of food aid in wheat was barely one fourth of its average international price (Saran and Konandreas 1991). This cost is further reduced if account is taken of the fact that much food aid has been provided on concessional or easy credit terms and donors recover part of the cost over time.

For various reasons, however, the opportunity costs of food aid have been increasing and may now be close to the world price of the donated food commodities. For importing food aid donors, the opportunity cost necessarily lies above the world price. Even for exporters, however, the offsetting factors are less important than before. Food aid is now a much smaller part of world trade in the main food aid commodities, so its leverage effect on world prices is also that much smaller. Donors increasingly bear the non-food costs of food aid, such as the costs of procurement, transport and delivery to the final destination, and these have been increasing. Moves to source a higher proportion of food aid deliveries in developing countries through triangular transactions, as favoured by the EU, also raise the opportunity cost. Thus the putative cost advantages of food aid, and which helped to make the case for additionality in the past, are now much less persuasive and attractive to those running foreign aid programmes. 


\section{Implications of Uruguay Round Agreement}

The implementation of the Uruguay Round Agreement on Agriculture will impact on future food aid flows. Some commentators have argued that the Agreement could encourage a more favourable attitude to food aid donations, particularly if it fails to prevent the continued generation of food surpluses and high subsidy costs in developed countries. Because subsidisation of exports is disciplined under the Agreement, bona fide food aid may be the only outlet for exporting countries (Singer and Shaw 1996). These authors argue that increased food aid flows could assist the liberalisation objectives of the Agreement by removing a substantial overhang of food from commercial markets which would facilitate the adjustments required by developed countries while giving time for commercial markets to grow in developing countries. However, as the emergence of surplus food stocks would be a sign of inadequate adjustment to the disciplines of the Agreement, it is not clear why the food aid option would not simply become a crutch to postpone the necessary reforms rather than facilitating them.

The more likely outcome is that the reform process will reduce the availability of food surpluses in the future. As these have been positively associated with food aid levels in the past, the Agreement will probably lead to reduced food aid volumes. The higher world market prices resulting from the Agreement will also reduce volumes, given fixed food aid budgets. This interpretation is supported by the large downward adjustment from 7.52 to 5.35 million tonnes of cereals which the donor countries made in 1995 to their minimum food aid commitments under the Food Aid Convention and by the decline in actual food aid deliveries documented above. 
The Agreement included a Decision on Measures Concerning the Possible Negative Effects of the Reform Programme on Least-Developed and Net FoodImporting Developing Countries. The Decision establishes mechanisms which provide for: (i) review of the level of food aid and the initiation of negotiations in the appropriate forum to establish a level of food aid commitments sufficient to meet the legitimate needs of developing countries during the reform programme; (ii) the adoption of guidelines to ensure that an increasing proportion of food aid is provided to the least developed and nonfood importing developing countries in fully grant or highly concessional forms; (iii) financial and technical assistance under aid programmes to improve agricultural productivity and infrastructure; and (iv) differential treatment in the context of an agreement to be negotiated on agricultural export credits. The Decision also takes into account the question of access to the resources of international financial institutions under existing facilities, or such facilities as may be established, in order to address short-term difficulties in financing normal levels of commercial imports. The follow-up to these commitments is monitored by the WTO Committee on Agriculture but to date they have not led to substantive action.

\section{Conclusions}

Official development assistance to developing countries declined in volume terms throughout the 1990s. The focus of this paper has been on the declining share within this total of external assistance to agricultural development and food aid. The paper has proposed some explanations for these trends, and it has highlighted their detrimental impact on one of the most basic human rights, to food security. When the world community met in Rome at the World Food Summit in November 1996, it adopted the Rome Declaration on World Food Security which pledged its commitment to achieve food security for 
all and to an ongoing effort to reducing the number of undernourished people to half their present level no later than 2015. It further committed the donor community to make efforts to mobilise technical and financial resources from all sources, including external debt relief for developing countries, to reinforce national actions to implement sustainable food security policies. As we approach the new millenium, what are the prospects that these words will be translated into a reversal of aid commitments to agricultural development and the improvement of nutrition?

The review of the reasons for the decline in external assistance to agriculture highlighted a number of issues: the poor performance on average of some types of agricultural projects; the complexity and cost of lending to agriculture; the futility of project aid in a hostile policy environment to agricultural development; the influence of farming and environmental lobbies in developed countries; crowding out by lending for structural adjustment and debt relief, as well as for social and environmental objectives; the reduction in specialised agricultural staff in external assistance agencies; and falling international agricultural commodity prices.

The paper has highlighted the predominant role of the international financial institutions in providing official development finance for agricultural development. Thus it is important that the World Bank Rural Development Action Plan produced in October 1996 recognised that attention to rural development had declined in the World Bank Group. It proposed a series of measures to redress this situation and put forward a series of revised principles intended to guide World Bank lending in this area in the future. The Bank has also tackled the problem of poorly-performing agricultural projects. The proportion of satisfactory or better projects in the agricultural portfolio had increased to 78 per cent in 1995, 10 percentage points above the Bank average 
for all projects in that year. The Action Plan sets a target of satisfactory ratings for at least 80 per cent of completed projects by the year 2000 and beyond, recognising that improved project performance is essential to increased commitment both inside and outside the World Bank Group.

The Plan recognises that the 80 per cent satisfactory rating target by the year 2000 is its only quantitative target. Crucially, no targets are set for overall lending to agriculture. Indeed, it is recognised that increased lending volume in recipient countries which agree to buy into higher priority for agriculture and rural development will be offset by a complete or nearly complete withdrawal from countries where efforts to build a consensus on giving higher priority to agriculture fail. Nonetheless, the Plan clearly hopes that a renewed commitment by the Bank to agricultural lending will send a signal both to other donors and to developing countries which will lead to an overall increase in the volume of flows.

There is evidence that other donors are beginning to follow suit. For example, the EU states that it 'has made food security a priority in development policy' and that 'the range of development policy instruments, whether in the framework of the Lomé Convention or in the framework of other agreements with different regions, is increasingly centred upon priorities for food security.' (European Commission, 1996). Certainly, favourable policy changes to encourage agricultural development within many developing countries, as well as the steps taken to open agricultural markets in the Uruguay Round, create a more positive environment for new agricultural aid projects compared to the past.

While these create the potential for increased external assistance to agriculture, reversing the declining trend in aid volumes will require active political support in donor countries. The views of development NGOs and 
agricultural interest groups are particularly important. NGO are rightly concerned that aid should be directed towards the most vulnerable communities and households. Much agricultural aid in the past, which went to promote export agricultural crops, irrigation projects and large-scale land development, failed to have a clear poverty focus. Not surprisingly, NGO support went instead to increasing aid flows to areas such as environmental protection and the social sector. One of the requirements for rebuilding support for increased agricultural aid will be to re-think the strategy of agricultural development in order to emphasise the links with poverty alleviation. One of the refreshing things about the World Bank Rural Development Action Plan is its explicit recognition of this requirement.

The influence of agricultural interest groups in the formulation of aid policy varies across countries and is more significant in the United States than in Europe. The United States is a major food exporter, and in periods of low world market prices and rising food surpluses, farmers have lobbied hard against extending aid to agricultural projects in developing countries which might provide additional competition. The extensive research on whether foreign aid complements or conflicts with the interests of US producers shows decisively that even farmers in the industrialised countries gain from faster agricultural growth in developing countries (as an example, see Rosegrant et al., 1995). This is a message which needs to be communicated again and again.

The prospects for a reversal of the decline in food aid are less marked. Food aid programmes will probably continue for the rest of this decade at the lower levels seen in recent years. Despite the evidence that the LIFDCs could absorb double the food aid volumes provided even in the peak year of 1993, the political coalitions which sustained food aid in the past have begun to dissipate and fragment. De-linking of food aid from agricultural policy may improve its 
quality, but also reduces political support for higher volumes. Food aid is now more competitive with financial aid and donors see few reasons why a higher proportion of shrinking financial aid budgets should be diverted to food aid. The pledge in the Decision attached to the Uruguay Agreement on Agriculture to review the level of food aid established under the Food Aid Convention 'to establish a level of food aid commitments sufficient to meet the legitimate needs of developing countries during the reform programme' will probably mean no further reduction in these commitments over the lifetime of the Agreement. These minimum commitments under the Food Aid Convention set a floor which guarantees the continuation of food aid programmes at more or less the current level, but there seems little reason for donors to exceed these levels in future.

The food security implications of this drop in food aid need to be carefully evaluated. Aid for emergencies will continue to have first call on food aid budgets. More careful targeting of food aid on the most needy countries is essential, but with 80 per cent of deliveries now going to to LIFDCs, there is little excess to be squeezed in this area. Project food aid is also likely to be protected because of the institutionalisation of WFP and NGO programmes which make effective use of this kind of aid. The main brunt of the reduction in food aid will fall on programme aid where the food security implications are more indirect and depend on the developmental use of the counterpart funds. Assuming these trends continue, then the nutritional impact of declining food aid budgets will be limited. It implies, however, an even greater responsibility to ensure that adequate financial aid is made available to overcome the barriers to access to food among poor and vulnerable households. The one event which might alter this prognosis would be a series of food emergencies leading to a massive growth in refugees and displaced persons. 
Table 1. Official commitments of external resources to agriculture (broad definition, millions constant 1990 US dollars).

\begin{tabular}{|l|r|r|r|r|r|}
\hline & $\mathbf{1 9 8 0 - 8 2}$ & $\mathbf{1 9 8 3 - 8 6}$ & $\mathbf{1 9 8 7 - 8 9}$ & $\mathbf{1 9 9 0 - 9 2}$ & $\mathbf{1 9 9 3 - 9 5}$ \\
\hline Total & 17,168 & 16,433 & 16,845 & 13,299 & 10,038 \\
\hline Bilateral & 6,415 & 6,020 & 7,510 & 5,394 & 4,035 \\
\hline Multilateral & 11,283 & 10,413 & 9,335 & 7,905 & 6,002 \\
\hline Share bilateral \% & $37 \%$ & $37 \%$ & $45 \%$ & $40 \%$ & $40 \%$ \\
\hline
\end{tabular}

Sources: 1980-1990 data at constant 1985 prices from Von Braun et al., 1993; 1991-1995 data at 1990 prices from Statistical Analysis Service, FAO; 1985 prices converted to 1990 prices using the Export Manufactures Unit Value index from UNCTAD, Handbook of International Trade Statistics, 1993.

Table 2. External assistance to agriculture committed by the DAC countries

\begin{tabular}{|l|r|r|r|r|r|}
\hline Region & $\mathbf{1 9 9 1}$ & $\mathbf{1 9 9 2}$ & $\mathbf{1 9 9 3}$ & $\mathbf{1 9 9 4}$ & $\mathbf{1 9 9 5}$ \\
\hline & \multicolumn{5}{|c|}{ (US\$ million) } \\
\hline EU & 1,599 & 2,127 & 1,609 & 1,419 & 1,512 \\
\hline Japan & 1,354 & 2,101 & 1,562 & 1,500 & 2,218 \\
\hline US & 632 & 442 & 363 & 460 & 378 \\
\hline Other & 381 & 325 & 248 & 299 & 218 \\
\hline Total & 3,967 & 4,995 & 3,781 & 3,679 & 4,327 \\
\hline & \multicolumn{5}{|c|}{$($ per cent shares $)$} \\
\hline EU & $40.3 \%$ & $42.6 \%$ & $42.5 \%$ & $38.6 \%$ & $35.0 \%$ \\
\hline Japan & $34.1 \%$ & $42.1 \%$ & $41.3 \%$ & $40.8 \%$ & $51.3 \%$ \\
\hline US & $15.9 \%$ & $8.8 \%$ & $9.6 \%$ & $12.5 \%$ & $8.7 \%$ \\
\hline Other & $9.6 \%$ & $6.5 \%$ & $6.6 \%$ & $8.1 \%$ & $5.0 \%$ \\
\hline Total & $100.0 \%$ & $100.0 \%$ & $100.0 \%$ & $100.0 \%$ & $100.0 \%$ \\
\hline
\end{tabular}

Source: FAO Statistical Analysis Service, 1997

Table 3. Percentage of bilateral aid committed to production agriculture, 1985-95

\begin{tabular}{|l|r|r|r|}
\hline Region & $\mathbf{1 9 8 5 - 1 9 8 9}$ & $\mathbf{1 9 9 0 - 1 9 9 2}$ & $\mathbf{1 9 9 3 - 1 9 9 5}$ \\
\hline EU & $\%$ & $\%$ & $\%$ \\
\hline Japan & 13.2 & 8.6 & 8.0 \\
\hline US & 11.9 & 11.7 & 9.1 \\
\hline Others & 10.2 & 2.7 & 5.4 \\
\hline Total DAC & 14.8 & 9.5 & 7.6 \\
\hline
\end{tabular}

Source: OECD, Development Co-operation, various. Figures for the EU and Others are unweighted averages. Spain and Portugal only included in the EU total since 1991. Others include Australia, Canada, New Zealand, Norway and Switzerland. 
Table 4. Sectoral distribution of the lending of the Multilateral Development Banks for the years 1986, 1991 and 1996 (percentages)

\begin{tabular}{|l|r|r|r|r|r|r|r|r|r|r|r|r|}
\hline Sector & \multicolumn{4}{|c|}{ IBRD/IDA } & \multicolumn{4}{|c|}{ IDB/FSO } & \multicolumn{3}{|c|}{ AsDB/AsDF } & \multicolumn{3}{|c|}{ AfDB/AfDF } \\
\hline & 1986 & 1991 & 1996 & 1986 & 1991 & 1996 & 1986 & 1991 & 1996 & 1986 & 1991 & 1996 \\
\hline Agriculture & 29 & 16 & 12 & 21 & 11 & 8 & 41 & 21 & 15 & 37 & 24 & 13 \\
\hline $\begin{array}{l}\text { Other } \\
\text { productive }\end{array}$ & 45 & 40 & 37 & 48 & 35 & 17 & 41 & 66 & 57 & 53 & 58 & 55 \\
\hline Social & 11 & 22 & 27 & 21 & 11 & 30 & 14 & 13 & 13 & 10 & 3 & 4 \\
\hline Other & 16 & 23 & 26 & 10 & 44 & 46 & 5 & 0 & 16 & 0 & 14 & 29 \\
\hline Total & $\mathbf{1 0 0}$ & $\mathbf{1 0 0}$ & $\mathbf{1 0 0}$ & $\mathbf{1 0 0}$ & $\mathbf{1 0 0}$ & $\mathbf{1 0 0}$ & $\mathbf{1 0 0}$ & $\mathbf{1 0 0}$ & $\mathbf{1 0 0}$ & $\mathbf{1 0 0}$ & $\mathbf{1 0 0}$ & $\mathbf{1 0 0}$ \\
\hline
\end{tabular}

Source: OECD 1998, based on data compiled by the North-South Institute of Canada from the multilateral development banks' Annual Reports.

Table 5. EU multilateral aid by selected purposes, 1986-1995

\begin{tabular}{|l|r|r|r|}
\hline Sector & $\mathbf{1 9 8 6 - 1 9 8 9}$ & $\mathbf{1 9 9 0 - 1 9 9 2}$ & $\mathbf{1 9 9 3 - 1 9 9 5}$ \\
\hline Food aid & 18.7 & 18.9 & 10.1 \\
\hline Humanitarian aid & 2.9 & 7.4 & 11.9 \\
\hline Agriculture & 9.6 & 7.9 & 5.5 \\
\hline Rural development & 8.8 & 2.4 & 0.9 \\
\hline
\end{tabular}

Source: Cox and Koning, 1997

Table 6. Distribution of bilateral aid commitments by major purpose, per cent

\begin{tabular}{|l|r|r|r|r|r|r|}
\hline Purpose & $\mathbf{1 9 8 2 - 8 3}$ & $\mathbf{1 9 8 7 - 8 8}$ & $\mathbf{1 9 8 9 - 9 0}$ & $\mathbf{1 9 9 1 - 9 2}$ & $\mathbf{1 9 9 3 - 9 4}$ & $\mathbf{1 9 9 4 - 9 5}$ \\
\hline $\begin{array}{l}\text { Social and } \\
\text { administrative } \\
\text { infrastructure }\end{array}$ & 22.1 & 24.6 & 23.3 & 20.2 & 26.2 & 29.0 \\
\hline $\begin{array}{l}\text { Economic } \\
\text { infrastructure }\end{array}$ & 21.3 & 19.5 & 17.0 & 17.5 & 20.4 & 22.7 \\
\hline Agriculture & 12.1 & 12.0 & 8.6 & 7.2 & 7.5 & 7.4 \\
\hline $\begin{array}{l}\text { Industry and other } \\
\text { production }\end{array}$ & 15.1 & 7.8 & 5.8 & 6.3 & 3.9 & 3.1 \\
\hline Food aid & 6.9 & 5.5 & 3.6 & 3.3 & 3.2 & 1.2 \\
\hline Programme assistance & 13.5 & 16.4 & 11.9 & 11.6 & 7.5 & 5.8 \\
\hline Other (inc debt relief) & 11.0 & 14.4 & 29.7 & 34.2 & 31.5 & 30.7 \\
\hline Total & $\mathbf{1 0 0}$ & $\mathbf{1 0 0}$ & $\mathbf{1 0 0}$ & $\mathbf{1 0 0}$ & $\mathbf{1 0 0}$ & $\mathbf{1 0 0}$ \\
\hline
\end{tabular}

Source: OECD, Development Co-operation Annual Reports, Paris. The classification used in the first column may not be exactly similar to that used from 1987-88 onwards. 
Table 7. Global food aid deliveries, 1988-96

\begin{tabular}{|l|r|r|r|r|r|r|r|r|r|}
\hline & $\mathbf{1 9 8 8}$ & $\mathbf{1 9 8 9}$ & $\mathbf{1 9 9 0}$ & $\mathbf{1 9 9 1}$ & $\mathbf{1 9 9 2}$ & $\mathbf{1 9 9 3}$ & $\mathbf{1 9 9 4}$ & $\mathbf{1 9 9 5}$ & $\mathbf{1 9 9 6}$ \\
\hline Total food aid & 14848.3 & 11733.6 & 13641.8 & 13195.9 & 15219.0 & 16846.1 & 12644.8 & 9845.8 & 7488.2 \\
\hline $\begin{array}{l}\text { Low-income, food } \\
\text { deficit countries }\end{array}$ & 12812.2 & 9455.1 & 10083.2 & 11064.7 & 12148.6 & 10443.3 & 9868.3 & 7571.9 & 5823.6 \\
\hline $\begin{array}{l}\text { Proportion of cereal } \\
\text { imports of LIFDCs } \\
\text { covered by food aid (\%) }\end{array}$ & 15 & 14 & 17 & 16 & 16 & 12 & 11 & & 9 \\
\hline
\end{tabular}

Source: WFP (Interfais); FAO, Food Aid in Figures and Food Outlook for last row

Table 8. Global food aid deliveries by category for 1988-94

\begin{tabular}{|l|r|r|r|r|}
\hline Years & Total & Programme & Relief & Project \\
\hline & \multicolumn{3}{|c|}{ (million tonnes) } \\
\hline $1988-90$ & 13408.0 & 7340.5 & 2812.2 & 3255.3 \\
\hline $1991-92$ & 14202.0 & 7156.3 & 4265.4 & 2780.3 \\
\hline $1993-94$ & 14880.5 & 7223.4 & 4403.3 & 2753.9 \\
\hline & \multicolumn{3}{|c|}{ (per cent) } \\
\hline $1988-90$ & $100 \%$ & $55 \%$ & $21 \%$ & $24 \%$ \\
\hline $1991-92$ & $100 \%$ & $50 \%$ & $30 \%$ & $20 \%$ \\
\hline $1993-94$ & $100 \%$ & $49 \%$ & $30 \%$ & $19 \%$ \\
\hline
\end{tabular}

Source: WFP (Interfais)

Table 9. Total food aid by region

\begin{tabular}{|l|r|r|r|r|}
\hline & $1988-1990$ & $\mathbf{1 9 9 1 - 9 2}$ & $\mathbf{1 9 9 3 - 9 4}$ & $\mathbf{1 9 9 5 - 9 6}$ \\
\hline & \multicolumn{4}{|c|}{ (million tonnes) } \\
\hline Sub-Saharan Africa & 3558.6 & 5008.1 & 4560.9 & 2862.9 \\
\hline N.Africa/M.East & 2814.3 & 2340.5 & 1011.6 & 740.6 \\
\hline South/East Asia & 3770.4 & 2895.1 & 2283.0 & 2144.0 \\
\hline L. America/Caribbean & 2306.2 & 1929.8 & 1710.1 & 838.5 \\
\hline Europe and CIS & 958.5 & 2034.0 & 5180.0 & 2081.2 \\
\hline Total & 13407.9 & 14207.5 & 14745.5 & 8667.0 \\
\hline & \multicolumn{4}{|c|}{$($ per cent) } \\
\hline Sub-Saharan Africa & $27 \%$ & $35 \%$ & $31 \%$ & $33 \%$ \\
\hline N.Africa/M.East & $21 \%$ & $16 \%$ & $7 \%$ & $9 \%$ \\
\hline South/East Asia & $28 \%$ & $20 \%$ & $15 \%$ & $25 \%$ \\
\hline L. America/Caribbean & $17 \%$ & $14 \%$ & $12 \%$ & $10 \%$ \\
\hline Europe and CIS & $7 \%$ & $14 \%$ & $35 \%$ & $24 \%$ \\
\hline Total & $100 \%$ & $100 \%$ & $100 \%$ & $100 \%$ \\
\hline
\end{tabular}

Source: WFP (Interfais) 


\section{References}

Bhattacharjee, J., 1977, External assistance for food and agricultural development in the Third World, World Development 5, 5-7, 633-639.

Clay, E. and Stokke, O., 1991, Assessing the performance and economic impact of food aid: the state of the art, in Clay, E. and Stokke, O., eds., Food Aid Reconsidered: Assessing the Impact on Third World Countries, London, Cass.

Cox, A. and Koning, A., 1997, Understanding European Community Aid, London, Overseas Development Institute.

European Commission, 1996, EC Food Security and Food Aid Programme, Activity Report 1995/96, Brussels, European Commission.

European Council, 1996, Regulation on Food Aid Policy and Food Aid Management and Special Operations in Support of Food Security, No 1292/96, Brussels.

FAO, 1996a, Food, agriculture and food security: developments since the World Food Conference and prospects, Technical Background Document No. 1 for the World Food Summit, Rome.

FAO, 1996b, Investment in agriculture, Technical Background Document No. 10 for the World Food Summit, Rome.

FAO, 1997a, External Assistance to Agriculture, Statistical Analysis Service, Rome, FAO (mimeo).

OECD, 1998, Development Co-operation 1997, Paris, OECD.

Overseas Development Institute, 1997, Global Hunger and Food Security after the World Food Summit, Briefing Paper 1, February, London, ODI.

Rosegrant, M., Agcaoili-Sombilla, M. and Perez, N., 1994, Global Food Projections to 2020: Implications for Investment, Food, Agriculture and the 
Environment Discussion Paper 5, Washington, D.C., International Food Policy Research Institute.

Ruttan, V., 1993, Does food aid have a future?, in Ruttan, V., ed., Why Food Aid?, Baltimore, Johns Hopkins.

Saran, R. and Konandreas, P., 1991, An additional resource? A global perspective on food aid flows in relation to development assistance, in Clay, E. and Stokke, O., eds., Food Aid Reconsidered: Assessing the Impact on Third World Countries, London, Cass.

Shaw, D. and Singer, H., 1996, A future food aid regime: implications of the Final Act of the Uruguay Round, Food Policy, 21, 4/5, 447-460.

Shapouri, S., 1995, Food Aid Needs and Availabilities: Projections for 2005, GFA-6, Washington, D.C., US Department of Agriculture Economic Research Service.

Von Braun, J., Hopkins R., Puetz, D. and Pandya-Lorch, R., 1993, Aid to Agriculture: Reversing the Decline, Food Policy Report, Washington, D.C., International Food Policy Research Institute.

Von Braun, J., Hopkins, R., and Pandya-Lorch, R., 1994, The changing political economy forces of aid to agriculture, Agriculture + Rural Development, 1,1, 4-7.

World Bank, 1996, Rural Development: From Vision to Action, Paper prepared by the rural development staff of the World Bank, Washington, D.C., World Bank. 